\title{
Rotational stocking and production of Italian ryegrass on Argentinean rangelands
}

\author{
E.J. JACOBO, A.M. RODRIGUEZ, J.L. ROSSI, L.P. SALGADO, AND V.A. DEREGIBUS
}

Authors are assistant research scientists and professor, Department of Animal Science. Facultad de Agronomİa, Universidad de Buenos Aires. C1417DSE. Buenos Aires. Argentina.

\begin{abstract}
The decreased carrying capacity of Argentinian Flooding Pampa rangelands through the reduction of density of $\mathrm{C}_{3}$ grasses may be partially attributed to continuous stocking. The objective of this study was to evaluate the effectiveness of rotational vs. continuous stocking to improve winter forage production by incrementing the density of Italian ryegrass (Lolium multiflorum Lam.). Under rotational stocking, ryegrass seedlings established almost 2 months earlier in the fall and tiller density was 3-fold higher in winter than under continuous stocking. Aerial net primary productivity of $\mathrm{C}_{3}$ grasses was approximately 2 -fold greater under rotational compared with continuous stocking in the first and second years. This substantial increase in winter productivity supported almost 2 -fold increase in stocking rate (from 0.6 to1.0 AU ha' ${ }^{-1}$.
\end{abstract}

Key Words: winter forage production, temperate-humid rangeland, grazing systems, Lolium multiflorum.

The native temperate grasslands of the Argentinean Flooding Pampa occupies 5,000,000 ha in the eastern portion of central Argentina. This region is characterized by a mild, humid climate with low fertility soils (Soriano et al. 1991). This vast forage resource is utilized by cow-calf operations to produce yearlings that are weaned in autumn and fattened on cultivated pastures in the dryer Western Pampa. Frequent flooding prevents the replacement of native grasslands by cultivated pastures or crops. These grasslands support $\mathrm{C}_{3}$ and $\mathrm{C}_{4}$ grasses during the cool and warm seasons, respectively. Since the productivity of $\mathrm{C}_{4}$ grasses is 3fold greater than $\mathrm{C}_{3}$ grasses (Sala et al. 1981), forage production follows a seasonal pattern. During fall and spring, $\mathrm{C}_{3}$ and $\mathrm{C}_{4}$ grasses vegetate coincidently. Early in the fall, $\mathrm{C}_{3}$ grasses start to grow while $\mathrm{C}_{4}$ grasses end their growing period with a great quantity of accumulated biomass.

Continuous stocking of these grasslands by domestic herbivores since the last century has resulted in degradation (Deregibus and Cahuepé 1983). Grazing progressively reduced $\mathrm{C}_{3}$ grasses such as Stipa neesiana Trin, Melica brasiliana Arduinus and Piptochaetium montevidense Par.(León and Oesterheld, unpublished), which magnifies the seasonality of forage production.

We are grateful to Rodolfo Golluscio for his review, which greatly improve an earlier draft of this manuscript. This research was funded by the National Council of Research in Argentina (CONICET).

Manuscript accepted 17 Jan. 2000.

\section{Resumen}

La reducción de la receptividad de los pastizales naturales de la Pampa Deprimida (Argentina) como consecuencia de la disminución de la densidad de gramİneas $\mathrm{C}_{3}$ ha sido atribuida al pastoreo continuo. El objetivo de este estudio fue evaluar la capacidad del pastoreo rotativo con respecto al continuo de incrementar la producción invernal de forraje mediante la promoción de ryegrass anual (Lolium multiflorum Lam.). Bajo pastoreo rotativo, las plántulas de ryegrass se estalecieron dos meses más temprano en el otoño y la densidad de macollos fue 3 veces más alta en invierno que bajo pastoreo continuo. La productividad primaria neta aérea de las gramíneas $C_{3}$ fue aproximadamente 2 veces más alta bajo pastoreo controlado que bajo pastoreo continuo. Este significativo incremento en la productividad invernal permitió duplicar la carga animal (de 0.6 a $1 \mathrm{EV} \mathrm{ha}^{-1}$ ).

This restriction may be overcome by incrementing the density of Italian ryegrass (Lolium multiflorum Lam.), an annual grass with high quality forage, native to the Mediterranean region. This species, together with wheat (Triticum aestivum L. em Tell.), has become widespread in Flooding Pampa grasslands since the beginning of this century.

Italian ryegrass seeds disperse late in spring and germinate the following autumn. During autumn and spring, competitive interactions among $\mathrm{C}_{3}$ and $\mathrm{C}_{4}$ grasses occur. The intensity is controlled by the availability of resources. Light quality, determined by canopy density, plays an important role in these interactions (Deregibus et al. 1983, Casal et al. 1985, 1986). Soil moisture and temperature allow the onset of the germination of Italian ryegrass seeds exposed on soil surface (Rodriguez et al. 1998), and if it is irradiated by direct sunlight, the germination is increased (Deregibus et al. 1994). This occurs whenever the canopy is intensively defoliated through high stocking rate at the end of the summer. As a consequence it would be possible to increase winter forage production through a grazing strategy designed to promote Italian ryegrass germination and seedling establishment (as shown in experiment I/II). The aim of this study was to evaluate the effectiveness of rotational vs. continuous stocking to improve winter Italian ryegrass production.

\section{Methods and Materials}

\section{Study area}

The study sites were located on 2 commercial farms of the Flooding Pampa region. Each farm consisted of approximately 
Table 1. Monthly precipitacion registered in the study site during the experimental period.

\begin{tabular}{lccc}
\hline \hline First period & Precipitation & Second period & Precipitation \\
\hline Mar 89 & $(\mathrm{mm})$ & Mar 90 & $(\mathrm{mm})$ \\
Apr 89 & 105 & Apr 90 & 65 \\
May 89 & 226 & May 90 & 372 \\
Jun 89 & 105 & Jun 90 & 10 \\
Jul 89 & 126 & Jul 90 & 46 \\
Aug 89 & 5 & Aug 90 & 7 \\
Sep 89 & 0 & Sep 90 & 12 \\
Oct 89 & 72 & Oct 90 & 36 \\
Nov 89 & 109 & Nov 90 & 28 \\
Dec 89 & 191 & Dec 90 & 51 \\
Jan 90 & 50 & Jan 91 & 51 \\
Feb 90 & 72 & Feb 91 & 787 \\
TOTAL & 34 & TOTAL & \\
\hline
\end{tabular}

1,200 ha of native grasslands for cow-calf operations. Annual precipitation (average from 1958 to 1988 ) is $920 \mathrm{~mm}$ evenly distributed throughout the year. Monthly temperatures (average from 1958 to 1988 ) range from $6.8^{\circ} \mathrm{C}$ in July-August to $21.8^{\circ} \mathrm{C}$ in January. Because of the flat relief and the occurrence of a high water table, soils belong to the halo-hydromorphic complex and associations (INTA 1977). Studies were conducted in a hydromorphic community, where dominant $\mathrm{C}_{4}$ grasses were Paspalidium paludivagum (Hitchc. et Chase) Parodi and Leersia hexandra $\mathrm{Sw}$; d dominant $\mathrm{C}_{3}$ grasses were Chaetotropis elongata (H.B.K.) Björkm. and Lolium multiflorum Lam.; and dominant spring-summer dicots were Alternanthera philoxeroides (Mart.) Griseb., Leontodon nudicaulis L. and Mentha pulegium $\mathrm{L}$.

During the experimental period (March 1989-February 1991) precipitation was recorded monthly (Table 1).

\section{Research layouts}

Two experiments were conducted simultaneously. Experiment I was located on a farm $\left(35 \mathrm{E}^{\circ} 30^{\prime} \mathrm{S}, 57^{\circ} 15^{\prime} \mathrm{W}\right) 160 \mathrm{~km}$ south of Buenos Aires. It was designed to study whether the increment of Italian ryegrass germination under rotational stocking led to an earlier and denser establishment of ryegrass than did continuous stocking. Experiment II was conducted on a farm $\left(36^{\circ} 25^{\prime} \mathrm{S}, 5^{\circ} 05^{\prime} \mathrm{W}\right) 240 \mathrm{~km}$ southwest of Buenos Aires with the objective of determining whether rotational stocking was able to improve winter Italian ryegrass productivity compared to continuous stocking.

\section{Grazing treatments}

Grasslands of both farms had been continuously stocked at 0.65 cows ha ${ }^{-1}$ by
Angus and Hereford cow/calf pairs for more than 25 years. The mean weight of cows was $420 \mathrm{~kg}$, the breeding season occurred from November to January and calves were weaned during April at 6 to 8 months of age with an average weight of $170 \mathrm{~kg}$. Because the physiological status of herds changed throughout the year, the stocking rate gradually decreased from 0.8 animal unit (AU) ha ${ }^{-1}$ in March when cows weaned calves in the last month of lactation to $0.5 \mathrm{AU} \mathrm{ha}^{-1}$ in winter (from May to July) after weaning of calves. Since March 1989, this grazing method was replaced by rotational stocking on both farms except for paddocks that were maintained under continuous stocking as a control treatment. Rotational stocking was performed by concentrating the cow-calf herd and moving it through a series of 10-12 paddocks with an average size of 45 ha. The annual average stocking rate was $1 \mathrm{AU} \mathrm{ha}^{-1}$, varying between 1.3 $\mathrm{AU} \mathrm{ha}^{-1}$ in March to 0.8 $\mathrm{AU} \mathrm{ha}^{-1}$ in winter (from May to July). This represented an increase of $54 \%$ in the average stocking rate compared to continuous stocking. Occupation period in each paddock varied between 3 to 15 days and rest period between 25 to 90 days according to the growth rate of forage species. During the occupation period imposed in early autumn, nearly all the available biomass was removed to increase Italian ryegrass germination followed by about 90 days rest to allow seedling development. During the occupation periods imposed in spring only around $50 \%$ of the available biomass was grassed. This allowed the cattle to make the selection and the ryegrass plants to flower and seed.

\section{Germination and establishment of Italian ryegrass.}

In late summer (end of February), approximately 2 months after seed shed,
15 frames $(10 \times 20 \mathrm{~cm})$ were placed randomly beneath the canopy in 50 ha paddocks that were either continuously or rotationally stocked (3 paddocks per treatment). To determine Italian ryegrass seed bank, a soil sample $(20 \times 10 \times 5 \mathrm{~cm})$ was taken next to each frame. These 15 samples were gathered to obtain a composite sample for each paddock and Italian ryegrass seeds were extracted by sieving. Immediately after this, a 4-day grazing period was implemented on rotationally stocked paddocks, during which cattle removed nearly all the available biomass. At the end of this period, canopy height inside each frame was measured. Italian ryegrass seedling and tiller densities were recorded after approximately 4, 45, 75, and 120 days from the end of the grazing period on rotationally stocked paddocks. Measurements on continuously stocked paddocks were performed on the same sampling dates. The experiment was performed in 1989 and repeated in 1990.

Regression analysis was performed between the seed bank and seedling density recorded during autumn in 1989 and 1990. To analyze the response curves of seedling density over time under different grazing treatments and years, a nonparametric split-plot analysis using the Kruskal-Wallis rank analysis to test the among-experimental-units source of variation and the Friedman statistic for the within-experimental-unit variation was utilized (Potvin and Lechowicz 1990). Data recorded in the first 3 sampling dates were analyzed as repeated measures. In the fourth sampling date, when Italian ryegrass plants were tillering, tiller density was recorded and compared using Tukey's test $(\mathrm{P}<0.05)$.

\section{$\mathrm{C}_{3}$ and $\mathrm{C}_{4}$ grass productivity}

This experiment was performed using a single replicate per grazing treatment, rotationally or continuously stocking, in 40 and 60 ha paddocks respectively.

Total aboveground biomass was harvested from March 1989 to May 1991 before and after each occupation period in the rotationally stocked paddock. Thirty $0.25 \mathrm{~m}^{2}$ areas were randomly located and clipped to ground level on each date. In the continuously stocked paddock, thirty, $1 \mathrm{~m}^{2}$ cages were randomly placed to avoid the access of large herbivores. Biomass samples were obtained inside each $0.25 \mathrm{~m}^{2}$ cage and outside by clipping to ground level whenever the rotationally stocked paddock was grazed. After each clipping, cages were moved to a new location. Those 30 samples were composited then 
separated randomly in 3 new groups. These samples were hand separated into 6 components (green and standing dead material of $\mathrm{C}_{3}$ and $\mathrm{C}_{4}$ grasses, dicots and grasslikes), oven dried at $70^{\circ} \mathrm{C}$ and weighed. Within the $\mathrm{C}_{3}$ component, dry matter of Italian ryegrass was weighed separately.

Above-ground net primary productivity (ANPP) of $\mathrm{C}_{3}$ and $\mathrm{C}_{4}$ grasses in rotationally stocked paddocks was estimated as the difference between the accumulated green biomass for each component at the end of each rest period and the remnant biomass left after the previous occupation period, divided by the number of days of the rest period. In the continuously stocked paddock, ANPP was similarly calculated as the difference between the green biomass accumulated within the cages and the existing biomass when the cages were placed, divided by the number of days of the period. To reduce the masking effect in the estimation of senescence in the productivity of each group of grasses, any daily increment of standing dead biomass for both compartments was added to the respective green productivity value (Sala et al. 1981). Annual production was estimated as the summation of the ANPP of each period multiplied by the duration of the corresponding period.

To analyze the overall pattern of ANPP of $\mathrm{C}_{3}$ and $\mathrm{C}_{4}$ grasses over time and the differences in their trends between grazing treatments, the multivariate procedure for repeated measures experiments proposed by Gurevitch and Chester (1986) and the correction method for unequally spaced measurements proposed by Robson (1959) were employed. This procedure was applied for the first (26 April 1989-10 December 1989) and the second (13 April 1990-7 January 1991) sampling period of $\mathrm{C}_{3}$ grasses and for the first (12 July 198918 March 1989) and second (28 August 1990-25 March 1991) sampling period of $\mathrm{C}_{4}$ grasses. A Tukey's test $(\mathrm{P}<0.05$ ) was applied to compare annual production of $\mathrm{C}_{3}$ and $\mathrm{C}_{4}$ grasses and total forage production.

\section{Results and Discussion}

\section{Germination and establishment of Italian ryegrass.}

The seed bank of Italian ryegrass recorded in late summer ranged from 13,500 to 31,800 seed $\mathrm{m}^{-2}$ and showed a low association $(-0.23>r>0.35)$ with seedling density recorded during autumn.

The pattern of Italian ryegrass seedling

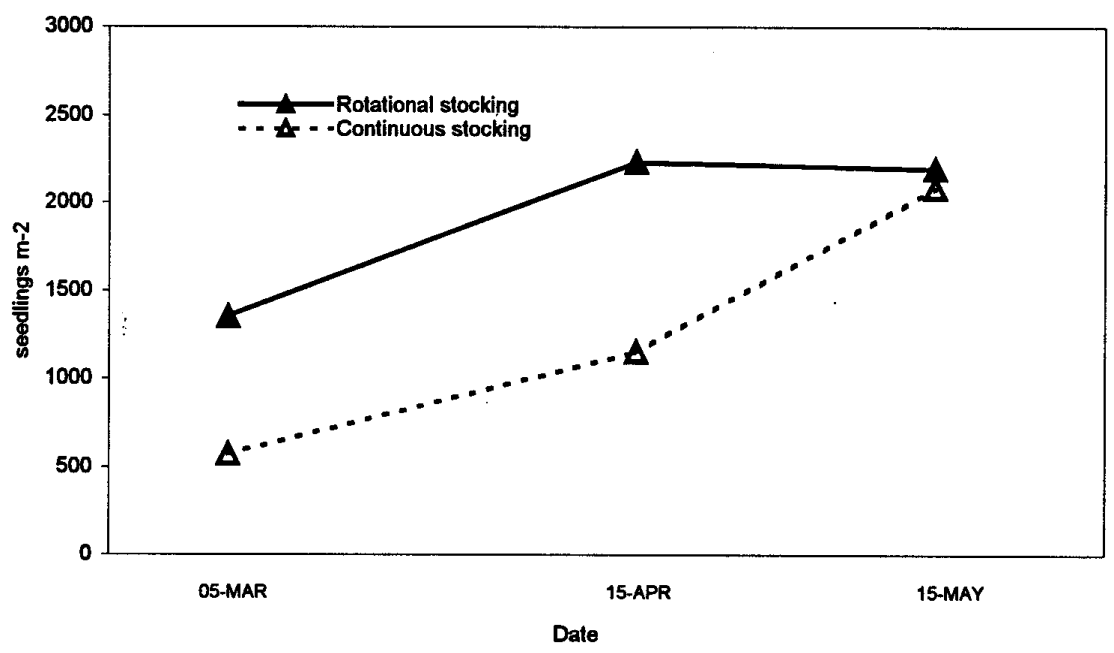

Fig. 1. Pattern of ryegrass seedling appearance during autumn under continuous or rotational stocking.

density is plotted in Figure 1. As the repeated measures analysis showed that the factor "Year" and the interactions "Year x Grazing" and "Year x Time" were not significant (Table 2), each point in

Table 2. Non-parametric split-plot analysis of ryegrass seedling density over time under different grazing treatments and years.

\begin{tabular}{lcc}
\hline \hline Sources & Statistic & $\mathrm{P}$ \\
\hline Among experimental units & & \\
Year & 0.0256 & 0.8728 \\
Grazing & 8.3077 & 0.0039 \\
Year x Grazing & 0.0476 & 0.8273 \\
Within experimental units & & \\
Time & 8.101 & 0.0411 \\
Year x Time & 6.001 & 0.1116 \\
Grazing x Time & 0.606 & 0.8981 \\
\hline
\end{tabular}

Figure 1 is the average of data recorded in the corresponding sampling dates of 1989 and 1990. The highly significant effect of factors "Grazing" and "Time" (Table 2) indicates that grazing treatments modified the pattern of Italian ryegrass seedling appearance. In rotationally stocked paddocks seedlings established earlier and in a greater abundance than in continuously stocked paddocks (Fig.1). This was partially due to the promotion of germination obtained through the removal of the dense $\mathrm{C}_{4}$ grass canopy to a $3.5 \mathrm{~cm}$ stubble height $(\mathrm{CV}=12 \%)$ during the grazing period performed in early autumn, because canopies shorter than $5 \mathrm{~cm}$ height allow sunlight illumination of Italian ryegrass seeds (Deregibus et al. 1994). Conversely in continuously stocked paddocks a canopy of $8.3 \mathrm{~cm}$ stubble height $(\mathrm{CV}=$
$73 \%$ ) during early autumn shaded a great proportion of seeds. These seeds would germinate only when their period of lightsensitivity is over in late autumn (Rodriguez et al. 1998), therefore maximum germination was achieved 1 month later than in rotationally stocked paddocks (Fig.1).

The earlier establishment of Italian ryegrass seedlings under rotational stocking may account for the large differences in ryegrass tiller density between grazing treatments found in early winter (end of June), 3,094 seedlings $\mathrm{m}^{-2}$ in rotational stocking compared to 1,173 seedlings $\mathrm{m}^{-2}$ in continuously stocking. Similar values of tiller density were previously reported (Jacobo et al. 1995). Those seedlings, established earlier under rotational stocking, developed under low competition without being disturbed by grazing during the following rest period ( 90 days). This occured in the wet, temperate autumn season. Nevertheless, a long fall rest (135 days) without removal of the canopy is not enough to increase Italian ryegrass density (Hidalgo and Cahuepé 1991).

\section{$\mathrm{C}_{3}$ and $\mathrm{C}_{4}$ grass productivity.}

Grazing treatment resulted in different patterns of ANPP for $\mathrm{C}_{3}$ grass (Fig. 2). Different linear trends were found for the first (26 April 1989-10 December 1989) and the second (13 April 1990-7 January 1991) sampling period (Table 3 ). The greater ANPP values obtained from April to September for rotational stocked paddock in 1989 and 1990 (Fig. 2) resulted in almost 2-fold greater annual production $\left(1,377\right.$ and $1,135 \mathrm{~kg}$ dry matter $\mathrm{ha}^{-1}$ in the first and second growing period respec- 
Table 3. ANOVA's for linear to fifth degree contrasts generated from data of ANPP of $C_{3}$ and $C_{4}$ grasses under rotational or continuous stocking.

\begin{tabular}{|c|c|c|c|c|c|c|c|c|c|c|c|c|c|}
\hline \multicolumn{14}{|c|}{ ANPP of $C_{3}$ grasses during the first sampling period ( 26 Apr $89-10$ Dec 89 ) } \\
\hline \multirow[t]{2}{*}{ Source } & \multirow[t]{2}{*}{ df } & \multicolumn{2}{|c|}{$1^{\text {st }}$ order } & \multicolumn{2}{|c|}{$2^{\text {nd }}$ order } & \multicolumn{2}{|c|}{$3^{\text {rd }}$ order } & \multicolumn{2}{|c|}{$4^{\text {th }}$ order } & \multicolumn{2}{|c|}{$5^{\text {th }}$ order } & \multicolumn{2}{|c|}{ Total } \\
\hline & & MS & F & MS & F & MS & $\mathbf{F}$ & MS & $\mathbf{F}$ & MS & F & MS & $\mathbf{F}$ \\
\hline Grand mean & 1 & 382 & 0.58 & 134558 & 3.94 & 4146 & 0.24 & 2806 & 0.01 & 1354817 & 3.20 & & \\
\hline Trat. & 1 & 11516 & $17.56 *$ & 66760 & 1.95 & 7489 & 4.70 & 18590 & 0.07 & 1095149 & 2.58 & 1317458 & 1.19 \\
\hline Error & 4 & 656 & & 34182 & & 17616 & & 252266 & & 424004 & & 1106985 & \\
\hline \multicolumn{14}{|c|}{ ANPP of $C_{3}$ grasses during the second sampling period (13 Apr $90-7$ Jan 91) } \\
\hline \multirow[t]{2}{*}{ Source } & df & \multicolumn{2}{|c|}{$1^{\text {st }}$ order } & \multicolumn{2}{|c|}{$2^{\text {nd }}$ order } & \multicolumn{2}{|c|}{$3^{\text {nd }}$ order } & \multicolumn{2}{|c|}{$4^{\text {th }}$ order } & \multicolumn{2}{|c|}{$5^{\text {th }}$ order } & \multicolumn{2}{|c|}{ Total } \\
\hline & & MS & F & MS & $\mathrm{F}$ & MS & $\mathbf{F}$ & MS & F & MS & $F$ & MS & F \\
\hline Grand mean & 1 & 23 & 0.00 & 588560 & 2.85 & 38939 & 0.89 & 43713 & 0.87 & 289945 & 1.03 & & \\
\hline Trat. & 1 & 93041 & $7.18 *$ & 59 & 0.00 & 41897 & 0.96 & 44537 & 0.89 & 286730 & 1.02 & 48391 & 0.01 \\
\hline Error & 4 & 12954 & & 206446 & & 43694 & & 50093 & & 281197 & & 6503847 & \\
\hline \multicolumn{14}{|c|}{ ANPP of $\mathrm{C}_{4}$ grasses during the first sampling period (12 Jul $89-18 \mathrm{Mar} 90$ ) } \\
\hline \multirow[t]{2}{*}{ Source } & df & \multicolumn{2}{|c|}{$1^{\text {st }}$ order } & \multicolumn{2}{|c|}{$2^{\text {nd }}$ order } & \multicolumn{2}{|c|}{$3^{\text {rd }}$ order } & \multicolumn{2}{|c|}{$4^{\text {th }}$ order } & \multicolumn{2}{|c|}{$5^{\text {th }}$ order } & \multicolumn{2}{|c|}{ Total } \\
\hline & & MS & $\mathbf{F}$ & MS & $\mathrm{F}$ & MS & $\mathbf{F}$ & MS & F & MS & F & MS & $\mathbf{F}$ \\
\hline Grand mean & 1 & 105790 & 3.54 & 275956 & 2.88 & 10098 & 0.40 & 11228 & 0.10 & 276905 & 0.04 & & \\
\hline Trat. & 1 & 28173 & $9.42 *$ & 189949 & 1.98 & 30441 & 4.86 & 3754 & 0.03 & 2150509 & 0.31 & 436567 & 0.30 \\
\hline Error & 4 & 2992 & & 95843 & & 25035 & & 110595 & & 7047056 & & 1465951 & \\
\hline \multicolumn{14}{|c|}{ ANPP of $\mathrm{C}_{4}$ grasses during the second sampling period (28 Aug $90-25 \mathrm{Mar} 91$ ) } \\
\hline \multirow[t]{2}{*}{ Source } & df & \multicolumn{2}{|c|}{$1^{\text {st }}$ order } & \multicolumn{2}{|c|}{$2^{\text {nd }}$ order } & \multicolumn{2}{|c|}{$3^{\text {rd }}$ order } & $4^{\text {th }}$ or & & $5^{\text {th }}$ ord & & Total & \\
\hline & & MS & $\mathbf{F}$ & MS & $F$ & MS & $F$ & MS & $F$ & MS & $F$ & MS & $F$ \\
\hline Grand mean & 1 & 3657 & 4.61 & 44961 & 2.25 & 1039 & 0.08 & 462 & 0.01 & 106682 & 0.10 & & \\
\hline Trat. & 1 & 12757 & $16.07 *$ & 9655 & 0.48 & 13618 & 1.10 & 1814 & 0.04 & 409367 & 0.40 & 255242 & 0.20 \\
\hline Error & 4 & 794 & & 19994 & & 12424 & & 43428 & & 1017524 & & 1199511 & \\
\hline
\end{tabular}

tively) compared to continuous stocking (610 and $\left.731 \mathrm{~kg} \mathrm{DM} \mathrm{ha}^{-1}\right)$. Under both grazing treatments, Italian ryegrass was the major component of this group of grasses (avg. $77 \%)$. In view of these results, we conclude that earlier seedling establishment and an increase in Italian ryegrass density obtained under rotational stocking, are the major determinants of the substantial increase in winter production.
This result shows that rotational stocking may overcome the major negative effect of continuous stocking in these grasslands.

Patterns of ANPP of $\mathrm{C}_{4}$ grasses were different between grazing treatments (Fig. 3 ), as significantly different linear trends 


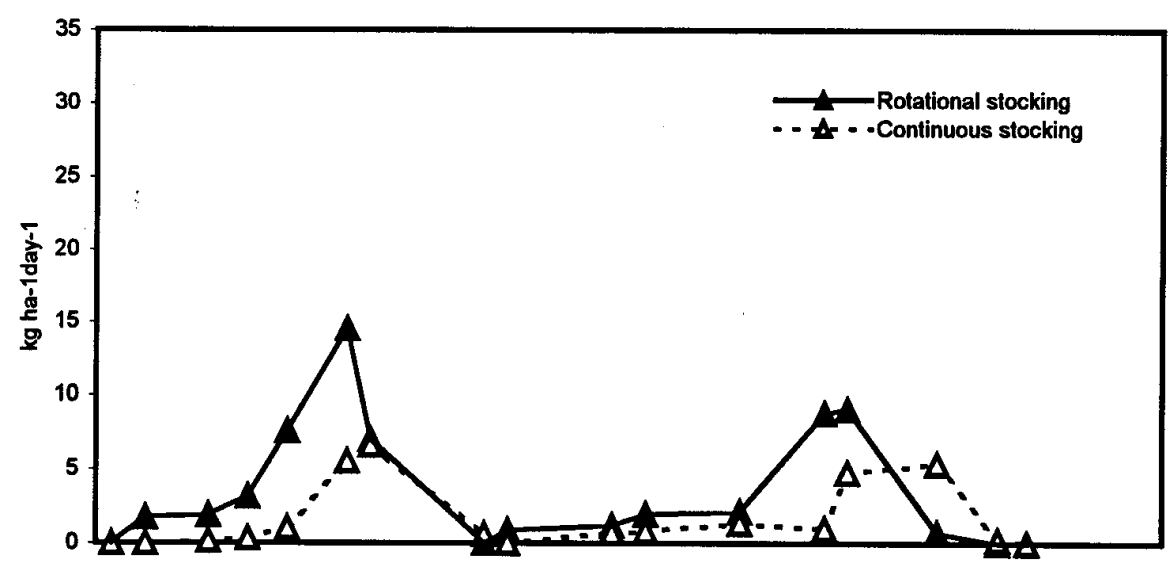

MAR-89 MAY-89 JUL-89 SEP-89 NOV-89 JAN-90 MAR-90 MAY-90 JUL-90 SEP-90 NOV-91 JAN-91 MAR-91 MAY-91

Fig. 2. Aboveground net primary productivity of $\mathrm{C}_{3}$ grasses under continuous or rotational stocking.

were found for the first (12 July 1989-18 March 1989) and the second (28 August 1990-25 March 1991) sampling period (Table 3). The lower values of ANPP observed under rotational stocking (Fig.3) resulted in a decrease in annual production of $\mathrm{C}_{4}$ grasses $\left(2,127\right.$ and $1,088 \mathrm{~kg} \mathrm{DM} \mathrm{ha}^{-1}$ in the first and second year) respective to continuous stocking $(3,250$ and $1,846 \mathrm{Kg}$ $\left.\mathrm{DM} \mathrm{ha}^{-1}\right)$. This decrease may be a consequence of the increasing competition from the greater population of Italian ryegrass during spring, when ryegrass biomass increases exponentially because of reproductive growth.

Because the increase of $\mathrm{C}_{3}$ grass production was accompanied by a reduction in $\mathrm{C}_{4}$ grass production under rotational stocking, total annual production of all grasses was similar among treatments in

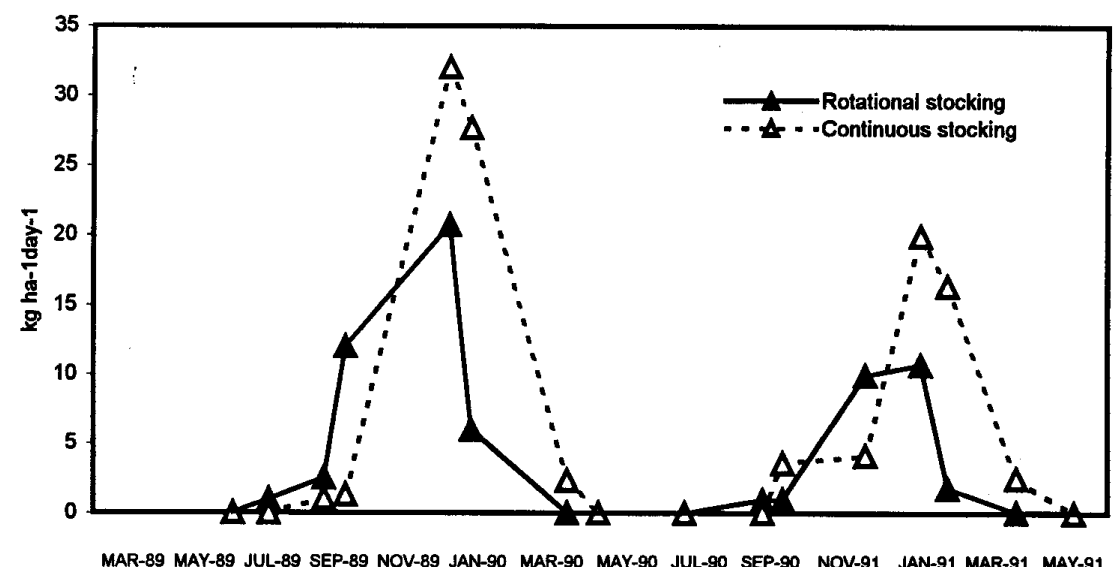

Date

Fig. 3. Aboveground net primary productivity of $\mathrm{C}_{4}$ grasses under continuous or rotational stocking.
Although the scope of this experiment must be considered very carefully due to limited replication, the results are useful because it is the first comparison of ANPP under rotational and continuous grazing in this region.

We conclude that the earlier establishment of Italian ryegrass and the consequent greater winter forage production explains the increase of stocking-rate supported under rotational stocking compared to continuous stocking (1.0 vs 0.6 average AU ha-1). Under rotational stocking the period of low forage availability may be overcome earlier, so cows may lose less weight during winter supporting improved body condition prior to breeding.

\section{Literature Cited}

the first $\left(3,504\right.$ and $\left.3,860 \mathrm{~kg} \mathrm{DM} \mathrm{ha}^{-1}\right)$ and in the second year $(2,223$ and $2,577 \mathrm{~kg}$ DM ha ${ }^{-1}$ ). Therefore, grazing treatment had no relevant impact on overall ANPP, a well documented fact in grazing system literature (Van Poollen and Lacey 1979, Hart et al. 1989, O'Reagain and Turner 1992, Biondini and Manske 1996). The reduction of annual production under both grazing treatments in 1990 (Table 3) was due to the lower precipitation registered in that year (Table 1).

The distribution of total forage productivity $\left(\mathrm{C}_{3}\right.$ and $\mathrm{C}_{4}$ grasses) was affected by rotational stocking as the changes in $\mathrm{C}_{3}$ and $\mathrm{C}_{4}$ grass production reduced seasonal variability in forage on offer. This contrasts with Heitschmidt et al. (1987) who reported no difference between rotational and continuous stocking in herbage distribution.

Biondini, M.E. and L. Manske. 1996. Grazing frequency and ecosystem processes in a northern mixed prairie, USA. Ecol. Appl. 6(1):239-256.

Casal, J.J., V.A. Deregibus, and R.A. Sanchez, 1985. Variations in tiller dynamics and morphology in Lolium multiflorum Lam. vegetative and reproductive plants as affected by differences in Red/Far-Red irradiation. Ann.of Bot., 56:553-559.

Casal, J.J., R.A. Sanchez, and V.A. Deregibus, 1986. The effect of plant density on tillering: The involvement of R/FR ratio and the proportion of radiation intercepted per plant. Environ. and Exp. Bot., 26(4):365-371.

Deregibus, V.A. and M.A. Cahuepé. 1983. Pastizales naturales de la Depresión del Salado: utilización basada en conceptos ecológicos. Rev. de Invest. Agrop. INTA, Bs. As., Argentina, XVIII:47-78.

Deregibus, V.A., R.A. Sanchez, and J.J. Casal, 1983. Effects of light quality on tiller production in Lolium spp. Plant Phys. 72:900-902.

Deregibus, V.A., J. Casal, E. Jacobo, D. Gibson, M. Kauffman, and A. Rodriguez. 1994. Evidence that heavy grazing may promote the germination of Lolium multiflorum seeds via phytochrome-mediated perception of high red/far-red ratios. Funct. Ecol. 8:536-542.

Gurevitch, J. and S.T. Chester. 1986. Analysis of repeated measures experiments. Ecol. 67(1):251-255.

Hart, R.H., M.J. Samuel, J.W. Waggoner, and M.A. Smith. 1989. Comparisons of grazing systems in Wyoming. J. Soil and Water Conserv. 44(4):344-347.

Heischmidt, R.K., S.L. Dowhower, and J.W. Walker. 1987. Some effects of a rotational grazing treatment on quantity and quality of available forage and amount of ground litter. J. Range Manage. 40(4):318-321. 
Hidalgo, L.G. and M.A. Cauhépé. 1991. Effects of seasonal rest in aboveground biomass for a native grassland of the flooding Pampa, Argentina. J. Range Manage. 44(5):471-475.

INTA. 1977. La Pampa Deprimida. Condiciones de drenaje de sus suelos. Publ.154. Departamento de Suelos, Instituto Nacional de Tecnologİa Agropecuaria, Buenos Aires, $167 \mathrm{pp}$

Jacobo, E., A. Rodríguez, and V.A. Deregibus. 1995. Effect of the nature and intensity of autumn grazing events on establishment of Italian Ryegrass in humid temperate rangelands. Proc. Fifth International Rangel. Congr., Salt Lake City, Utah.
O'Reagain, P.J. and J.R. Turner. 1992. An evaluation of the empirical basis for grazing management recommendations for rangeland in southern Africa. J. Grassl. Soc. South. Afr. 9(1):38-49.

Potvin, C. and M. Lechowicz. 1990. The statistical analysis of ecophysiological response curves obtaines from experiments involving repeated measures. Ecol. 7(14):1389-1400.

Rodríguez, A.M., E.J. Jacobo, and V.A. Deregibus. 1998. Germination behaviour of Italian ryegrass in flooding pampa rangelands. Seed Sci. Res. 8(4):521-528.

Robson, D.S. 1959. A simple method for construction of orthogonal polinomials when the independent variable is unequally spaced. Biometrics. 15: 187-191.
Sala, O.E., V.A. Deregibus, T. Schlichter, and H. Alippe. 1981. Productivity dynamics of a native temperate grassland in Argentine. J. Range Manage. 34:48-51.

Soriano, A. León, R.J.C., O.E. Sala, R.S. Lavado, V.A. Deregibus, M.A. Cahuepé, O.A. Scaglia, C.A. Velazquez, and J.H. Lemcoff. 1991. Rio de la Plata grasslands. In: RT Coupland (ed). Ecosystems of the world. Elsevier, Amsterdam, 367-407 pp.

Van Poollen, H.W. and J.R. Lacey. 1979. Herbage response to grazing systems and stocking intensities. J. Range Manage.32(4):250-253. 